\title{
Effect of growth hormones in induction of callus, antioxidants, and antibacterial activity in Nerium odorum
}

\author{
Avinash Prakasha, S Umesha* \\ Department of Studies in Biotechnology, University of Mysore, Manasagangotri, Mysore, Karnataka, India.
}

\begin{tabular}{|c|c|}
\hline $\begin{array}{l}\text { Article history: } \\
\text { Received on: December } 25,2017 \\
\text { Accepted on: February } 24,2018 \\
\text { Available online: May 22, } 2018\end{array}$ & $\begin{array}{l}\text { Nerium odorum is an imperative species with worldwide therapeutic and commercial uses. } N \text {. odorum has been } \\
\text { considered as a potentially important plant for industrial and pharmacological applications. Callus induction } \\
\text { potential of } N \text {. odorum was assessed from leaf explants cultured on Murashige and Skoog's medium using different } \\
\text { plant hormonal treatments. A range of different concentrations of 6-benzylaminopurine, 1-naphthaleneacetic }\end{array}$ \\
\hline $\begin{array}{l}\text { Key words: } \\
\text { Nerium odorum, } \\
\text { Growth hormones, } \\
\text { Callus, } \\
\text { Antioxidant, } \\
\text { Antibacterial activity }\end{array}$ & $\begin{array}{l}\text { acid, } 2,4 \text {-dichlorophenoxyacetic acid }(2,4-\mathrm{D}) \text {, indole-3-acetic acid (IAA), and kinetin }(0.5-5.0 \mathrm{mg} / \mathrm{L}) \text { have been } \\
\text { incorporated in the culture medium to investigate the biomass, polyphenols production and oxidizing and antibacterial } \\
\text { activity of the callus. The results showed highest callus induction at } 2.0 \mathrm{mg} / \mathrm{L} \text { in growth hormone combination of } \\
\text { IAA and 2,4-D. The total phenolic content was } 92.14 \mathrm{mg} \mathrm{GA} / \mathrm{g} \text { dry weight }(\mathrm{DW}) \text {. In addition, the } 2,2 \text {-diphenyl-1- } \\
\text { picrylhydrazyl activity and } 2,2 \text {-azinobis-(3-ethylbenzthiazoline-6-sulfonic acid) activities were } 46.7 \mu \mathrm{g} / \mathrm{mL} \mathrm{DW} \\
\text { and } 19.9 \mu \mathrm{g} / \mathrm{mLDW} \text {, respectively. Interestingly, the explants produced hard calli using combination of IAA and 2,4- } \\
\mathrm{D} \text { presented a higher phenolic content and antioxidant capacity when compared to individual growth hormones of } \\
\text { either IAA or 2,4-D. Altogether, these results demonstrate the extraordinary effect of different growth hormones on } \\
\text { polyphenols production, antioxidant, and antibacterial activities in } N \text {. odorum. }\end{array}$ \\
\hline
\end{tabular}

\section{INTRODUCTION}

Nerium odorum Linn., commonly identified as rose ray, is an evergreen shrub, used as ornamental plant belongs to family Apocynaceae, omnipresent in temperate and subtropical regions of Africa, Europe, and South East Asia. The plant is widely grown in Indian gardens and found in humid and coastal areas including Assam, Arunachal Pradesh, Himachal Pradesh, Rajasthan, Karnataka, and in all parts of India. $N$. odorum plant is one of the most toxic plants of this family and it is effective in snakebite cure. The crushed leaves, twig, root, and bark are used as a rat poison and as an insecticide too. The root is suggested for external appliance to skin diseases, and the plant is popular medication for mental or venereal diseases as abortifacient in traditional medicine. The oil extracted from the root bark is suggested for medication against leprosy, epilepsy, and scaly nature of skin/skin diseases. The $N$. odorum leaves consist of minute quantity of latex which is used to make rubber [1].

$N$. odorum produces several secondary metabolites among these alkaloids are having a number of pharmacological attention and even primary compounds such as cardenolides, flavonoids, and terpenes have their own attention. Oleandrin has been recognized as effective antitumor

*Corresponding author:

S. Umesha, Department of Studies in Biotechnology, University of Mysore,

Manasagangotri, Mysore, Karnataka, India.

E-mail: su@appbot.uni-mysore.ac.in compound; in addition, it is used indigenously as a cardiac tonic and diuretic. $N$. odorum is recognized to be toxic against extensive range of tumor cells, and this plant also recognized as antioxidants, the leaves of $N$. odorum contain two novel cytotoxic pentacyclic and trans-Karenin and potential secondary metabolites [2]. Similar reports are also indicated the occurrence of oleandrin, folineriin, adynerin, and digitoxigenin cardiac glycosides in N. odorum [3]. The plant seeds consist of about $12 \%$ of 9-hydroxy-isoricinoleic acid. Methanolic extract of the leaves was found to be anticonvulsant, central nervous system depressant, and analgesic. $N$. odorum extracts have been reported to for oleanolic acid. Lipid peroxidation inhibitory activity from flowers of $N$. odorum was reported earlier [4]. N. odorum plants with milky sap have a high medicinal value; the enlarge demands of $N$. odorum plant for industrial and commercial exploitation require a substitute rate of proliferation.

During these decades, in vitro practice of callus culture is being extensively useful to produce indistinguishable quality of callus and disease-free plants. In observation of this evidence, the study was conducted for in vitro propagation of $N$. odorum. The cultured plant callus is extensively accepted as capable alternative for the production of secondary metabolites [5-7]. The opportunity of housing cell and tissue cultures for secondary metabolites production has been investigated, but the yield has not been optimized to reach higher levels for commercial application $[8,9]$.

In the literature, no reports are available on the effect of growth hormones and their interactions toward secondary metabolites 
production, antioxidant, and antibacterial activities in callus cultures of $N$. odorum. In this connection, the present study aims for to compare the effects of different growth hormones, on the production of total phenols, antioxidant, and antimicrobial activities of $N$. odorum callus.

\section{MATERIALS AND METHODS}

\subsection{Collection of Explants, Implantation, and Culture Conditions}

The $N$. odorum, plant materials, was brought from plants grown in the Botanical Garden of University of Mysore, Mysore, Karnataka, India. An authentic sample was identified by taxonomist and the voucher specimen was submitted to the herbarium of the Department of Studies in Biotechnology, University of Mysore, Mysore. Leaves of 8-12 cm length were collected from $N$. odorum plants growing at an altitude of $2400 \mathrm{~m}$ at location $12^{\circ} 18^{\prime} 29.45^{\prime \prime} \mathrm{N}$ and $76^{\circ} 38^{\prime} 18.83^{\prime \prime} \mathrm{E}$ in the area of Mysore region, Karnataka, in June 2015 and were used for callus initiation.

\subsection{Initiation of Callus Cultures}

The newly formed young leaves excised from $N$. odorum were further sterilized in $0.5 \%(\mathrm{w} / \mathrm{v})$ mercuric chloride used for $15 \mathrm{~min}$ and washed for 5 times for $5 \mathrm{~min}$ each in sterile $\mathrm{H}_{2} \mathrm{O}$. N. odorum leaves were cut into small pieces and inoculated to a sterile Murashige and Skoog's (MS) medium for callus initiation [10], supplemented with $8 \%$ agar, along with 2,4-dichlorophenoxyacetic acid (2,4-D), indole3-acetic acid (IAA), 6-benzylaminopurine (BAP), kinetin (Kin), and 1-naphthaleneacetic acid (NAA) (Hi-Media, Bangalore, India) at different concentration of $0.5-5 \mathrm{mg} / \mathrm{L}$. The sucrose was used as a single carbon source; the $\mathrm{pH}$ optimized to 5.8 before autoclaving with $1 \mathrm{~N} \mathrm{NaOH}$ and HCL. The explants on the medium were incubated at $24^{\circ} \mathrm{C} \pm 2{ }^{\circ} \mathrm{C}$ under diffuse fluorescent light (72/71 intensity) in an 18 -h photoperiod. Calli were maintained with regular subculturing on a monthly basis which was originated from the explants within 21 days.

\subsection{Determination of Callus Fresh/Dry Weight (FW/DW) and Callus Moisture Content}

The callus was collected from tissue culture laboratory after 40 days of inoculation, and its media was completely washed with sterile distilled water. The calluses were placed beneath a fan (on blotting paper) to remove water and the weight of callus was weighed in a balance. Subsequently, the calli were positioned on Petri dishes and heated in an oven for $10 \mathrm{~min}$ at $65^{\circ} \mathrm{C}$ for drying. DW of callus was determined in an electronic balance. The moisture content was determined using the FW and DW of callus by the following procedures of Rashmi and Trivedi [11].

$\mathrm{A}=$ Weight of empty Petri dish

$\mathrm{B}=$ Weight of Petri dish with fresh calli

$\mathrm{C}=$ Weight of Petri dish with dried calli

Moisture content $\%=(\mathrm{B}-\mathrm{A})-(\mathrm{C}-\mathrm{A}) /(\mathrm{B}-\mathrm{A}) \times 100$

\subsection{Extract Preparation}

Calli on diverse growth hormones were harvested, $200 \mathrm{mg}$ of DW in each callus was successively extracted successively utilizing $500 \mathrm{ml}$ of non-polar, moderately polar, and polar solvents (Merck, Bangalore, India) in increasing polarity (hexane $<$ ethyl acetate $<$ methanol $<$ water) using a Soxhlet apparatus by continuous hot percolation (boiling point, $52-62^{\circ} \mathrm{C}$ ) until the solvent became colorless. The resultant solvent extracts were concentrated in a rotary evaporator (Thermo Scientific,
Germany) under controlled pressure. For the studies undertaken, the required amount of extract was weighed and solubilized in dimethyl sulfoxide $(1 \mathrm{mg} / \mathrm{ml})$ and was further diluted as indicated in the sections below.

\subsection{Determination of Antioxidant Activity}

2. 5. 1. Total phenolic content, 2,2-diphenyl-1-picrylhydrazyl (DPPH) scavenging assay, and 2,2'-azinobis-(3ethylbenzthiazoline-6-sulfonic acid) (ABTS) radical cation decolorization assay

The total polyphenols of the Soxhlet extracts were determined by Folin-Ciocalteu method as described by Pasko et al. [12]. The free radical scavenging capacity of Soxhlet extract was determined by DPPH and ABTs method following the procedures of Brand-Williams et al. [13] and Re et al. [14]. The experiments consisted of three replicates and were repeated 3 times.

\section{6. Antibacterial Activity}

The Gram-negative bacteria, Escherichia coli, Klebsiella pneumonia, Salmonella, and Shigella and the Gram-positive bacteria, Staphylococcus aureus and Bacillus subtilis were obtained from stock culture unit of the Department of Studies in Biotechnology, University of Mysore, Manasagangotri, Mysore, Karnataka, India, and used for the assay. The extracts were screened for antibacterial activity using well diffusion method. The Soxhlet extracts from callus $(100 \mu \mathrm{g} / \mathrm{ml})$ were added to wells seeded agar plates. The plates were incubated at $37^{\circ} \mathrm{C} \pm 2{ }^{\circ} \mathrm{C}$ for $16 \mathrm{~h}$. Chloramphenicol and methanol were used as positive and negative controls, respectively.

\section{7. Statistical Analysis}

All experiments including DPPH, ABTS, measurements of total phenolic content, and antimicrobial activity assay were conducted in triplicates and repeated for 3 times. The reported value for each sample was calculated as the mean and standard deviation of three independent experiments.

\section{RESULTS}

\section{1. Effects of Hormonal Treatments on Callus Induction}

Plant growth regulators are synthetic molecules used in plant tissue culture and supplemented at relatively low concentrations to work as signaling compounds for plant growth and development. In the present study, stem (nodal) and leaf were used as explants, in which leaf part of explants appear to be the best for callus induction which represents the results in accordance with the earlier reports Rashmi and Trivedi [11]. The MS medium, without any growth hormones, was unable to induce callus. Among all the growth hormones, IAA and 2,4-D hormones exhibited more competence in callus induction in individual along with their different combinations which correlate the earlier reports [11,15]. The MS medium supplemented with different combination of enzyme, with different concentration varying from 0.5 to $5 \mathrm{mg} / \mathrm{L}$ of IAA, NAA, 2,4-D, BAP, and Kin exhibited stimulation and induction of callus. The highest maximum callusing retort of $89 \%$ was observed at the $2.0 \mathrm{mg} / \mathrm{L}$ of IAA [Figure 1]. At $0.5 \mathrm{mg} / \mathrm{L}$ of IAA, the induction of callus response was very less; simultaneously, on increase in the hormonal concentration up to $2 \mathrm{mg} / \mathrm{L}$, the induction of callus response was very good. Interestingly, at $2.5 \mathrm{mg} / \mathrm{L}$, and onward, callusing response was reduced at $5 \mathrm{mg} / \mathrm{L}$, no callusing or growth was observed. 
It was pragmatic that the higher concentration of IAA in media had an inhibitory effect on the callus induction and proliferation. 2,4-D with various in different concentration ranging from 0.5 to $5 \mathrm{mg} / \mathrm{L}$ exhibited stimulatory effects on callus induction. Interestingly, there was no induction of callus formation was observed on leaf explants inoculated to MS media supplemented with $0.5-5 \mathrm{mg} / \mathrm{L}$ of Kin. With respect to BAP and NAA, maximum callusing response of $15 \%$ in leaves was noted on supplement of $3 \mathrm{mg} / \mathrm{L}$. A decreased concentration of BAP and NAA of $0.5-1.5 \mathrm{mg} / \mathrm{L}$ was unable to produce callus and higher concentration of $3.5 \mathrm{mg} / \mathrm{L}$ and above of BAP up to $5 \mathrm{mg} / \mathrm{L}$ in the MS media had inhibitory effect on callus induction [Table 1]. 2,4-D and IAA with different concentrations $(0.5-5 \mathrm{mg} / \mathrm{L})$ showed stimulatory effects on callus induction. Maximum callusing response of $91 \%$ in leaf explants was noted at $2 \mathrm{mg} / \mathrm{L}$ in combination of IAA and 2,4-D [Figure 1]. At $3 \mathrm{mg} / \mathrm{L}$ of IAA and $1 \mathrm{mg} / \mathrm{L} \mathrm{2,4-D,}$ swelling of callus was observed. At $5-10 \mathrm{mg} / \mathrm{L}$ of IAA and 2,4-D, no callusing or growth was observed. Media supplemented with different concentration of 2,4-D combinations with BAP, Kin, and NAA showed stimulatory effects on callus induction with maximum

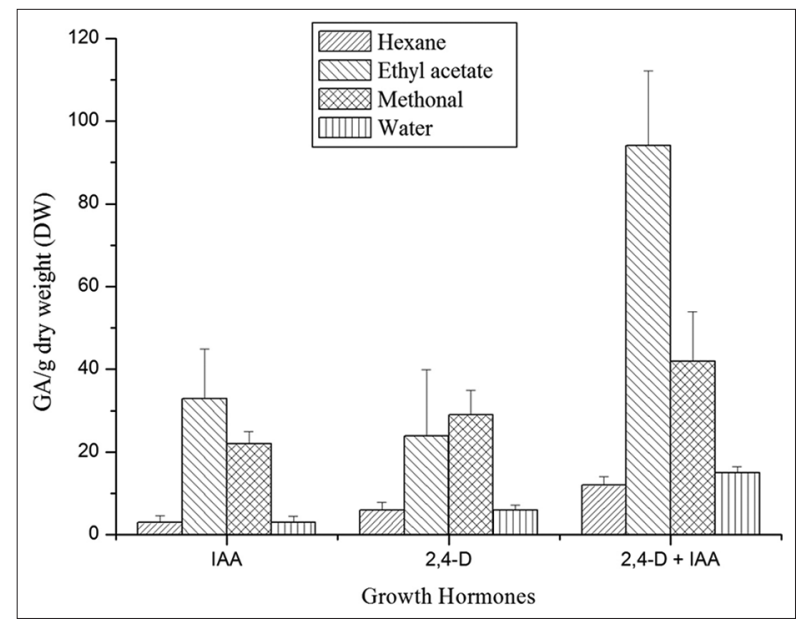

Figure 1: Callus induction of MS fortified with growth hormones. A; 2,4-D $(2.5 \mathrm{mg} / \mathrm{L}), \mathrm{B}$; IAA $(2.0 \mathrm{mg} / \mathrm{L}), \mathrm{C}$; Combination of 2,4-D and IAA at concentration $2.0 \mathrm{mg} / \mathrm{L}$ respectively.
26\% [Table 1]. Similarly, IAA and BAP, IAA and Kin, and IAA and NAA combinations showed stimulatory effects on callus induction. Maximum callusing response of $60 \%$ was recorded at 0.5 and $2 \mathrm{mg} / \mathrm{L}$ for IAA combined with BAP, Kin, and NAA, respectively [Table 1]. It was observed that 2,4-D and IAA had enhanced callus growth in the presence of auxins. Plant growth hormones can be classified into different types according to their molecular structures and physiological functions. The most extensively used and studied class of plant growth regulators in plant tissue cultures were auxins. 2,4-D and IAA were effectively induced callus formation in many plant species. The result from this study revealed that the presence of 2,4-D and IAA in the culture media was essentially required to induce callus formation in this species even though the cytokinin was absent. The effectiveness of 2,4-D and IAA in inducing the callusing is attributed to its main characteristic which can stimulate cell division of plant tissues and strongly suppress organogenesis. It is also considered to be the most potent among any other commonly used auxins.

MS media supplemented with varying concentration of $0.5-2.0 \mathrm{mg} / \mathrm{L}$ of NAA and BAP exhibited significant effect on callus induction. The maximum highest callusing response (25\%) was recorded at 2.5 and $1 \mathrm{mg} / \mathrm{L}$ for BAP and NAA. Different concentrations of NAA and Kin did not show any stimulatory effects on callus induction. Maximum callusing response (17\%) was recorded at 1 and $1.5 \mathrm{mg} / \mathrm{L}$ for Kin and BAP. At $2.5-5 \mathrm{mg} / \mathrm{L}$ of Kin and BAP, no callusing or growth was observed. In the present work, BAP, NAA, and Kin either individually or in combination could not induce callus significantly. In further experiments, BAP and NAA were supplemented to the MS media in combination with auxins $(2,4-$ $\mathrm{D}$ and IAA). The optimum treatment for callus induction in this study was identified in MS medium supplemented with $2.0 \mathrm{mg} / \mathrm{L}$ 2,4-D and $2.0 \mathrm{mg} / \mathrm{L}$ IAA combination. The findings revealed that the supplementation of auxins at an optimum concentration and combination with 2,4-D and IAA is required to produce calli with the desirable morphology. The hormonal combination of 2,4-D and IAA was found effective in producing optimum callus induction in several plant species. The FW and DWs and moisture content showed good growth of callus on 2,4-D and IAA along with their combinations $[11,15,16]$.

Table 1: Callus induction on leaf explants on MS medium supplemented with different concentrations and combinations of growth hormones (mg/L) in Nerium odorum.

\begin{tabular}{|c|c|c|c|c|c|c|c|}
\hline $\begin{array}{l}\text { Medium } \\
\text { composition mg/L }\end{array}$ & $\begin{array}{l}\% \text { of callus } \\
\text { induction }\end{array}$ & $\begin{array}{l}\text { Degree of } \\
\text { callusing }\end{array}$ & $\begin{array}{l}\text { Day of callus } \\
\text { induction }\end{array}$ & $\begin{array}{c}\text { Fresh } \\
\text { weight (mg) }\end{array}$ & $\begin{array}{c}\text { Dry } \\
\text { weight (mg) }\end{array}$ & $\begin{array}{l}\text { Moisture } \\
\text { content (\%) }\end{array}$ & $\begin{array}{l}\text { Nature of } \\
\text { callus }\end{array}$ \\
\hline MS & - & - & - & - & - & - & - \\
\hline 2,4-D & 85 & +++ & 21 & 1.56 & 0.35 & 77.56 & Whitish \\
\hline BAP & 15 & + & 33 & 1.05 & 0.16 & 57.0 & Light green \\
\hline IAA & 89 & +++ & 24 & 1.82 & 0.59 & 67.5 & Yellow \\
\hline NAA & 15 & + & 28 & 0.96 & 0.28 & 70.0 & Yellow \\
\hline 2,4-D+IAA & 91 & +++ & 19 & 2.36 & 0.83 & 64.83 & Yellow \\
\hline 2,4-D+NAA & 16 & ++ & 28 & 0.95 & 0.36 & 62.10 & Whitish \\
\hline 2,4-D+BAP & 26 & ++ & 26 & 0.84 & 0.19 & 77.38 & Whitish \\
\hline $\mathrm{IAA}+\mathrm{NAA}$ & 27 & +++ & 30 & 0.6 & 0.15 & 75.0 & Yellow \\
\hline $\mathrm{IAA}+\mathrm{BAP}$ & 61 & + & 32 & 1.23 & 0.46 & 62.0 & Yellow \\
\hline
\end{tabular}

Callus growth observations by measuring \% of callus induction, degree of callusing, day of callus induction, callus fresh and dry weight, and nature of callus of randomly selected samples from different concentrations (milligrams per liter) of growth hormones of Nerium odorum leaf. (-) indicates no regeneration and ( + ) indicates status of callus induction, + : Poor, ++: Good, +++: Excellent. MS: Murashige and Skoog's, 2,4-D: 2,4-dichlorophenoxyacetic acid, BAP: 6-benzylaminopurine, IAA: Indole-3-acetic acid, NAA: 1-naphthaleneacetic acid, Kin: Kinetin. 


\section{2. Effects of Growth Hormones on Nature and Moisture Content of Callus}

The FW and DW of the callus was measured after various periods, the significant difference in $\mathrm{FW}$ and $\mathrm{DW}(P=0.01)$ was observed in the value of weight from callus initiation up to 6 months, whereas no significant differences were found at 6-9 months. The time involved of callus growth in its optimization of media and a uniform callus was obtained after 5 months with frequent subculturing. The values for FW and DW after 1 month were 256 and $53 \mathrm{mg}$, respectively. These FW and DWs increased rapidly to 3622 and 198, respectively, after 6 months by frequent subculturing. The FW and DW of callus from 6 to 9 months exhibited $268 \mathrm{mg}$ of callus increased to an average weight of $357 \mathrm{mg}$ every month in FW. Figure 1 depicts the callus cultures of $N$. odorum. Leaf callus was loose in texture and friable. It was white and yellow in color with different growth hormone treated with combinations of 2,4-D. Callus was compact and non-friable, light yellow to light green in color with different growth hormone in combinations of IAA [Table 1]. The moisture content varied in the callus derived from explants under the influence of various 2,4-D and IAA. It was observed that moisture content varied from $69 \%$ to $80 \%$ which supports good growth of callus.

\subsection{In Vitro Antioxidant Assays}

Three in vitro tests (total phenolic content, DPPH, and ABTS) were used to characterize antioxidant property of an isolated callus of $N$. odorum. The phenolic content of $N$. odorum callus cultures under different growth hormonal conditions is presented in Figure 2. The results show that the production of polyphenols was affected by the type of growth hormone used during the growth of callus. The total phenolic content of ethyl acetate extract was between 37.81 and $23.96 \mathrm{mg} \mathrm{GA} / \mathrm{g}$ DW for IAA and 2,4-D, respectively, except these for the all other growth hormone (BAP and NAA) the phenolic content have no significant effect. Interestingly, when comparing with the combination of IAA and 2,4-D, the production of polyphenols by callus of $N$. odorum is superior to the production of polyphenols by individual growth hormones IAA and 2,4-D, which exhibited a total phenolic content of $92.14 \mathrm{mg} \mathrm{GA} / \mathrm{g}$ DW [Figure 2].

The highest antioxidant potential was demonstrated by an ethyl acetate extract obtained from IAA and 2,4-D callus, whose radical scavenging activity, expressed as EC, was $19.9 \mu \mathrm{g} / \mathrm{mL}$ (in ABTS test) and $46.7 \mu \mathrm{g} /$ $\mathrm{mL}$ (in DPPH assay) [Figure 3]. The lowest scavenging activity, with EC (ABTS test) and $164 \mu \mathrm{g} / \mathrm{mL} \mathrm{IC50} \mathrm{values} \mathrm{of} \mathrm{about} 45.6 \mu \mathrm{gmL}$ (DPPH test), was demonstrated by the methonolic extract of 2,4-D callus [Figure 3]. Based on our studies, the antioxidant activities of this plant from leaves and stem and roots have been reported extensively $[5,6]$. Even then, there were no reports available by in vitro growth of callus, slight differences in the antioxidant activities do occur that solely depend on varieties, location, and growth conditions [17]. Overall, in the studied experiments, the estimation of the antioxidants capacity exhibited positive results by scavenging free radicals. The inhibition in the DPPH and ABTS activity was found more in leaf extraction callus developed in growth hormones IAA and 2,4-D combination. The ethyl acetate extracts of $N$. odorum from this family showed antioxidant properties through hydroxyl scavenging ability. In vitro studies indicated the ability to scavenge free radicals (hydroxyl ions) [18].

\section{4. Antibacterial Activity}

The ethyl acetate extracts of callus from $N$. odorum were highly inhibiting the growth of both Gram-positive and Gram-negative bacteria. The variation with respect to concentration of extract, the zone of inhibition was observed from 10 to $16 \mathrm{~mm}$ from the extracts of IAA and 2,4-D growth hormones [Table 2]. The extracts of 2,4D were most effective, exhibiting a zone of inhibition ranged from 19 to $24 \mathrm{~mm}$ for B. subtilis, K. pneumonia, and S. aureus, whereas the inhibition zone for $E$. coli ranged from 13 to $17 \mathrm{~mm}$. The extract of IAA showed zone of inhibition ranging from 8 to $16 \mathrm{~mm}$ against

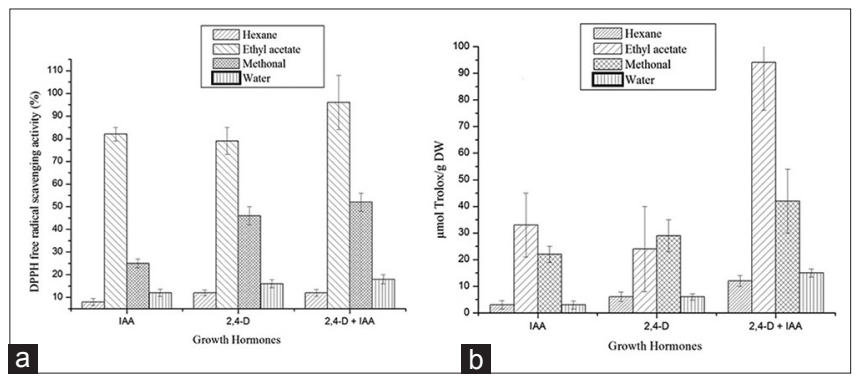

Figure 2: Total phenolic content in callus cultures of Nerium odorum under different growth hormonal conditions in different solvent extraction. The values are means of three individual experiments with three replicates. Bars indicate standard errors.

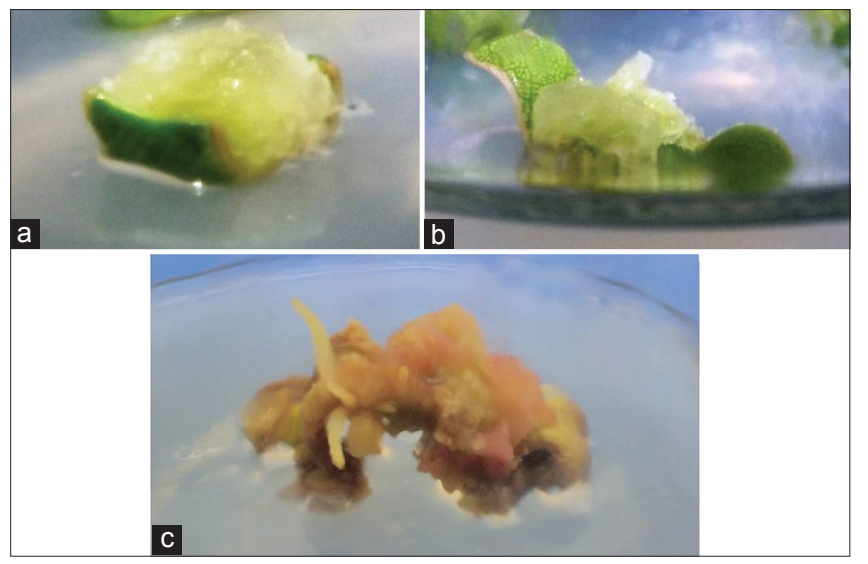

Figure 3: The DPPH and ABTS capacity of callus cultures of Nerium odorum under different growth hormonal conditions in different solvent extraction. The values are means of three individual experiments with three replicates. Bars indicate standard errors.

Table 2: Antimicrobial activity and the zone of inhibition of the ethyl acetate extracts from callus supplemented with different concentrations and combinations of growth hormones.

\begin{tabular}{lccc} 
Bacterial pathogens & \multicolumn{3}{c}{ Zone of inhibition (mm) } \\
\cline { 2 - 4 } & 2,4-D & IAA & 2,4-D+IAA \\
Escherichia coli & 10 & 12 & 12 \\
Klebsiella pneumoniae & 19 & 15 & 16 \\
Bacillus subtilis & 22 & 16 & 20 \\
Staphylococcus & 24 & 16 & 21 \\
Salmonella & 18 & 13 & 12 \\
Shigella & 12 & 16 & 11 \\
\hline
\end{tabular}

Extracts were screened for antibacterial activity using well diffusion method. The overnight culture was centrifuged and the pellet was resuspended in sterile water. The suspension of bacteria was plated on nutrient agar plates. The Soxhlet extracts from callus $(100 \mu \mathrm{g} / \mathrm{ml})$ were added to wells seeded agar plates. The plates were incubated at $37^{\circ} \mathrm{C}$ for 16 h. 2,4-D: 2,4-dichlorophenoxyacetic acid, IAA: Indole-3-acetic acid. 
K. pneumonia, B. subtilis, and E. coli [Table 2]. The antibacterial activity of the tuber may be due to the presence of phenolic active compounds in N. odorum. Antibacterial effect against Gram-negative and Gram-positive bacteria could be as natural source for producing pharmacological products $[19,20]$. The results of the current study supported the traditional treatment by medicinal plants and proposed antibacterial agents from plant extracts with antibacterial properties. The maximum activity was observed against Gram-negative and Gram-positive bacteria from ethyl acetate extract grown on 2,4D compared with IAA and along with the combination of IAA and 2,4-D, respectively. Antimicrobial properties of medicinal plants are being increasingly stated from various parts of the world. Based on the World Health Organization report, the plant active constituents are used as folk medicine in traditional therapies of $80 \%$ of the world's population $[20,21]$. In this study, the extracts obtained showed strong activity against most of the tested bacterial strains. The results were compared with standard drug. The effect of antibacterial in medicinal plants varies intensely depending on the phytochemical features of plant $[19,20]$.

\section{CONCLUSION}

Finally, it can be concluded that combinations of IAA and 2,4-D in MS media exhibited the highest calli formation from leaf explants of $N$. odorum. Our data revealed that calli subculture on IAA and 2,4-D was effective in increasing phenolic content and antioxidant property of IAA and 2,4-D exudation. This study also showed that ethyl acetate extracts from in vivo gave higher results for antioxidant activity and inhibition zone against Gram-negative and Gram-positive bacteria compared to the same concentration of callus extract from individual growth hormones (IAA/2,4-D). Further and more specific studies toward characterization of compounds, in vivo or in vitro, are recommended to determine the characteristics of secondary metabolites.

\section{ACKNOWLEDGMENTS}

This work was supported by the grants from DBT-MRP [BT/PR10406/ SPD/9/1232/2014]. Authors are grateful to IOE, University of Mysore, for spectral characterization and Chairman, DOS in Biotechnology, University of Mysore, Mysore-570006, for their infrastructure facilities.

\section{REFERENCES}

1. Zibbu G, Batra A. A review on chemistry and pharmacological activity of Nerium oleander L. J Chem Pharm Res 2010;2:351-8.

2. Siddiqui BS, Khatoon N, Begum S, Farooq AD, Qamar K, Bhatti HA, et al. Flavonoid and cardenolide glycosides and a pentacyclic triterpene from the leaves of Nerium oleander and evaluation of cytotoxicity. Phytochemistry 2012;77:238-44.

3. Bandara V, Weinstein SA, White J, Eddleston M. A review of the natural history, toxinology, diagnosis and clinical management of Nerium oleander (common oleander) and Thevetia peruviana (yellow oleander) poisoning. Toxicon 2010;56:273-81.

4. Dey P. Chaudhuri TK. Pharmacological aspects of Nerium indicum Mill: A comprehensive review. Pharm Rev 2014;8:156.

5. Lipsky KA. Problems of optimization of plant cell culture processes. J Biotechnol 1992;54:93-108.
6. McDonald KA, Jackman AP, Thorup JE, Dandekar AM. Plant callus as a source for biochemicals. Appl Biochem Biotechnol 1997;54:89-108.

7. Dix PJ. Plant Cell Line Selection. Weinheim: VCH; 1990. p. 4-17, 30-7, 187-211.

8. Yeoman MM, Yeomen CL. Manipulating secondary metabolism in cultured plant cells. Plant Cell Rep 1996;134:553-69.

9. Profumo P, Gastado AM, Riboldi CU. Formation of cardiac glycosides in calli from leaf explants of Nerium oleander L. Plant Med Phytother 1993;26:346-9.

10. Murashige T, Skoog F. A revised medium for rapid growth and bio assays with tobacco tissue cultures. Physiol Plant 1962;15:473-97.

11. Rashmi R, Trivedi MP. Effect of various growth hormone concentration and combination on callus induction, nature of callus and callogenic response of Nerium odorum. Appl Biochem Biotechnol 2014;172:2562-70.

12. Pasko P, Bartoń H, Zagrodzki P, Gorinstein S, Fołta M, Zachwieja Z. Anthocyanins, total polyphenols and antioxidant activity in amaranth and quinoa seeds and sprouts during their growth. Food Chem 2009;115:994-8.

13. Brand-Williams W, Cuvelier ME, Berset C. Use of a free radical method to evaluate antioxidant activity. Lebenson Wiss Technol 1995;28:25-30.

14. Re R, Pellegrini N, Proteggente A, Pannala A, Yang M, Rice-Evans C, et al. Antioxidant activity applying an improved ABTS radical cation decolorization assay. Free Radic Biol Med 1999;26:1231-7.

15. Sehrawat AR, Sanjogta U, Chowdhury JB. Establishment of plantlets and evaluation of differentiated roots for alkaloids in Rauwolfia serpentina. J Plant Biochem Biotechnol 2002;11:105-8.

16. Phelan S, Hunter A, Douglas GC. Effect of explants source on shoot proliferation and adventitious regeneration in 10 Buddleia cultivars. Sci Hortic 2009; 120:518-24.

17. Chidambaram U, Pachamuthu V, Natarajan S, Elango B, Suriyanarayanan, Ramkumar KM, et al. In vitro evaluation of free radical scavenging activity of Codariocalyx motorius root extract. Asian Pac J Trop Med 2013;6:188-94.

18. Farzinebrahimi R, Mat Taha R, Rashid KA, Ali Ahmed B, Danaee M, Rozali SE. Preliminary screening of antioxidant and antibacterial activities and establishment of an efficient callus induction in Curculigo latifolia Dryand (Lemba). Evid Based Complement Altern Med ECAM 2016;2016:6429652.

19. Biswas B, Rogers K, McLaughlin F, Daniels D, Yadav A. Antimicrobial activities of leaf extracts of guava (Psidium guajava L.) on two GramnegativeandGram-positive bacteria.IntJMicrobiol2013;2013:746165.

20. Oroojalian F, Kasra-Kermanshahi R, Azizi M, Bassami MR. Phytochemical composition of the essential oils from three Apiaceae species and their antibacterial effects on food-borne pathogens. Food Chem 2010;120:765-70.

21. Prakasha A, Grice ID, Kumar KV, Sadashiva MP, Shankar HN, Umesha S. Extracellular polysaccharide from Ralstonia solanacearum; A strong inducer of eggplant defense against bacterial wilt. Biol Control 2017;110:107-16.

How to cite this article:

Prakasha A, Umesha S. Effect of growth hormones in induction of callus, antioxidants, and antibacterial activity in Nerium odorum.

J App Biol Biotech. 2018;6(04):21-25.

DOI: $10.7324 / J A B B .2018 .60404$ 